ROCZNIK ADMINISTRACJI PUBLICZNEJ 2019 (5)

KOMUNIKATY / STUDY REPORTS

DOI 10.4467/24497800RAP.19.016.11479

http://www.ejournals.eu/RAP/

ISSN 2449-7800 (online), ISSN 2449-7797 (print), p. 250-254

HEORHII BASOV'

\title{
Using Conflict Resolution through Mediation to Address Problems that Might Arise with Decentralisation
}

\section{Preliminary issues}

As Ukraine continues its decentralisation process, there will inevitably be problems between the central government in Kyiv and the local village councils to which some powers are being devolved. Such conflicts can severely impact the success of the process as well as engender resentment towards the central government.

Research indicates that a model for political conflict resolution methods and processes involved in facilitating the peaceful ending of conflict and retribution - exists in many countries.

\section{Setting the stage for decentralisation}

Fumihiko Saito's seminal publication Foundations for Local Governance: Decentralisation in Comparative Perspective ${ }^{2}$ provides the basis for looking at decentralisation processes in certain developing countries (Uganda, Indonesia, India, Sri Lanka, Ghana and South Africa) and how successful or unsuccessful they were. Saito, however, is quite clear that "that effective public policy making would involve partnerships of diverse stakeholders between public, private, community and voluntary sectors" but "the decentralisation reforms are intended to contribute to further democratisation, to effective development, and to good governance. However, there is no automatic guarantee that these intended outcomes will be achieved just by decentralising political and administrative institutions."3

1 Heorhii Basov, a first-year student of Software Engineering, O. S. Popov Odessa National Academy of Telecommunications.

2 Foundations for Local Governance: Decentralisation in Comparative Perspective, F. Saito (ed.), Heidelberg: Physica-Verlag 2008.

3 Ibidem, VI. 
Saito is also very clear that "[o]ne of the essential messages of this book is that decentralisation per se does not necessarily lead to an improved governing arrangement between the leaders and citizens." ${ }^{4}$

\subsection{Definitions}

Before any discussion of the processes in question and their comparative successes, as well as a possible solution, it is necessary to define the terms that will be used in this article. All definitions are taken from the MerriamWebster's Collegiate Dictionary, Online Edition ${ }^{5}$.

\section{“CONFLICT}

2 a : competitive or opposing action of incompatibles : antagonistic state or action (as of divergent ideas, interests, or persons)

$<$ a conflict of principles $>$

b : mental struggle resulting from incompatible or opposing needs, drives, wishes, or external or internal demands

$<$ His conscience was in conflict with his duty.>"

For the purpose of this paper, both definitions are applicable when they are used to describe and discuss the needs, drives, wishes and demands of both the local and the central government.

\section{"DECENTRALISATION}

$1:$ the dispersion or distribution of functions and powers

$<$ a decentralisation of powers $>$;

specifically, government : the delegation of power from a central authority to regional and local authorities

$<$ the decentralisation of the state's public-school system $>$

$<$ government decentralisation $>$ "

This definition ties up well with the ideas presented in Saito's publication as well as the purpose of this paper.

\section{"MEDIATION}

the act or process of mediating; especially the intervention between conflicting parties to promote reconciliation, settlement, or compromise"

This is very important for a possible solution to conflicts that will arise between the central and local governments with decentralisation.

4 Ibidem, VII.

5 Merriam-Webster Collegiate Dictionary, http://unabridged.merriam-webster.com/ collegiate (accessed 7.7.2019). 


\section{“RESOLUTION}

1. $c$ : the act of determining

$<$ a court of resolution $>$

An important component of mediation and a result of both parties involved agreeing to a resolution beforehand.

"RULE OF LAW

a situation in which the laws of a country are obeyed by everyone [emphasis added]"

This concept is often overlooked when designing decentralisation or even a country's laws in general. Without rule of law, conflicts and abuses of the law will inevitably arise.

"SUBSIDIARITY

2. a principle in social organisation: functions which subordinate or local organisations perform effectively belong more properly to them than to a dominant central organisation".

Subsidiarity functions well only when there are clearly defined roles, rules, regulations and true exercise of local power.

\subsection{Areas of comparison}

Saito compares the studies in nine different areas (the reader is referred to the graph in Saito's work that delineates the results of various studies and allows for comparison) ${ }^{6}$. These areas are:

1. The state - what the government looked like before the decentralisation process began.

2. The transformation of the state - those areas of the state and its governance that are to be decentralised.

3. Rules of decentralisation - the purpose and the limits of the decentralisation process - was it true decentralisation or in name only.

4. Objectives of decentralisation - why does the country attempt to decentralise.

5. Civil society - how society itself views the rules and regulations governing it - were they to be obeyed or were they to be circumvented.

6. Market forces - the business aspect of a country; more importantly, how free the market is. Is it tightly controlled by a central government with arbitrary laws, nepotism, and bribery or was it clean and fair with rule of law?

6 Foundations for Local Governance: Decentralisation in Comparative Perspective, F. Saito (ed.), Heidelberg: Physica-Verlag 2008, p. 280-281. 
7. Partnerships - how were the interests of one facet of society connected with another facet with the same interests to form a stronger, more diverse advocacy, e.g. universities and businesses.

8. Autonomy of local government - how much true autonomy the local governments really had - was it real or in name only.

9. Synergy effects of partnerships - how well did the partnerships work and what can be done to make them better.

\section{Result of Study}

For a detailed description of the results of the studies and Saito's conclusions, the reader is referred to p. 277-286 of Foundations for Local Governance: Decentralisation in Comparative Perspective. However, in essence, Saito drew the following conclusions:

1. Decentralisation is a process to redefine the roles and responsibilities of the central and local governments. Whereas the phrase "nation building" is no longer commonly used, public sector restructuring in general, and decentralisation endeavours in particular, are indeed linked with the notion of nation building?

2. Decentralisation is essentially a political process ${ }^{8}$.

3. Any attempt to achieve "good governance" is far from an easy technical fix and "importing" and "transplanting" a process from another country without taking into consideration local variances is doomed to failure?.

4. Many donors are funding decentralisation projects and programmes without paying sufficient attention to the prominence of politics ${ }^{10}$.

\section{Conclusions}

While Saito and others in the publication address the problems that have and can occur with decentralisation, none approached the idea of mediation by a neutral party in resolving conflicts that occurred. Such an approach with a win-win foundation could allow conflicts to be resolved before they escalated.

This author recommends a detailed study of mediation projects that have worked and how they could possibly be implemented in countries that are attempting decentralisation.

\footnotetext{
7 Ibidem, p. 284.

8 Ibidem.

9 Ibidem, p. 285.

10 Ibidem.
} 


\section{Bibliography}

Merriam-Webster Collegiate Dictionary, http://unabridged.merriam-webster.com/ collegiate.

Foundations for Local Governance: Decentralisation in Comparative Perspective, Saito F. (ed.), Heidelberg, Physica-Verlag 2008, p. 301.

Abstract

As Ukraine continues its decentralisation process, there will inevitably be problems between the central government in Kyiv and the local village councils to which some powers are being devolved. Such conflicts can severely impact the success of the process as well as engender resentment towards the central government. Research indicates that a model for political conflict resolution - the methods and processes involved in facilitating the peaceful ending of conflict and retribution - exists in many countries. In China, for example, it is important that the solution is a "win-win" for the participants, that is, both sides of the conflict gain from its resolution. One successful model for conflict resolution is the use of trained neutral mediation from a Mediation Office or a similar body. This paper recommends exploring the concept of a Mediation Office as a possible option for Ukraine.

Keywords: conflict, decentralisation, mediation, resolution, rule of law, subsidiarity

\section{Rozwiązywanie sporów na drodze mediacji w celu niwelowania problemów spowodowanych decentralizacją \\ Streszczenie}

Podczas kontynuowania przez Ukrainę procesu decentralizacji niewątpliwie można spodziewać się wystąpienia problemów w relacjach rządu centralnego w Kijowie i lokalnych rad sołeckich, które otrzymują pewne uprawnienia. Napięcia takie mogą poważnie oddziaływać na powodzenie omawianego procesu oraz rodzić niechęć wobec rządu centralnego. Badania wskazują, że model rozwiązywania konfliktów politycznych oraz metody i procesy nakierowane na ułatwianie pokojowego zakończenia sporów i działań odwetowych istnieją w wielu krajach. Przykładowo w Chinach istotne jest, by rozwiązanie stanowiło wygraną dla obu stron, czyli aby obie zyskały coś na rozstrzygnięciu sporu. Udany model rozstrzygania sporów polega na wykorzystaniu przeszkolonych i zachowujących neutralność mediatorów Urzędu ds. Mediacji lub podobnego organu. W niniejszym artykule zaleca się dalsze badania dotyczące Urzędu ds. Mediacji jako jednej z organizacji prowadzących mediacje na Ukrainie.

Słowa kluczowe: spór, decentralizacja, mediacja, rozwiązywanie, praworządność, pomocniczość 